\title{
Poor science meets political neglect: Land use changes of high conservation value forests in Indonesia
}

\author{
Arnanto Nurprabowo ${ }^{1 *}$, San Afri Awang ${ }^{1}$, Sigit Hardwinarto ${ }^{2,3}$, Budi Dharmawan ${ }^{4}$, Muhammad \\ Haidar Daulay ${ }^{5}$, and Ahmad Maryudi ${ }^{5}$ \\ 1 Faculty of Forestry, Universitas Gadjah Mada, Yogyakarta, Indonesia \\ 2 Ministry of Environment and Forestry, Jakarta, Indonesia \\ 3 Faculty of Forestry, Mulawarman University, Samarinda, Indonesia \\ 4 Department of Agricultural Economics and Social Sciences, Universitas Jenderal Soedirman, Purwokerto, \\ Indonesia \\ ${ }^{5}$ Sebijak Institute (Research Center for Forest Policy \& History), Faculty of Forestry, Universitas Gadjah \\ Mada, Yogyakarta, Indonesia \\ * Correspondence author: prabowoarnanto@yahoo.com; Tel.: +62 813-1679-4999
}

\begin{abstract}
Forest land allocation and use in Indonesia have been politically contested and characterized by poor data and competing interests of different institutions. This study analyzes the process of integrating scientific findings in policymaking about land use and changes. The focus is on the processes related to the changes of Highly Important Forest Zones with Strategic Values (Dampak Penting Cakupan Luas dan bernilai Strategis/DPCLS). DPCLS forests are unique as any changes require approval from the parliament to complement the processes at the Ministry of Environment and Forestry and must be based on rigorous scientific evaluation. This study uses the case of Riau Islands (Kepri) Province, previously part of Riau Province, which to date is one of only two Indonesian provinces yet to accept the forest zonings of the Ministry. The province's strategic positions as exclusive economic and free trade zones make it further interesting in terms of land allocation as land becomes increasingly valuable for other uses. This paper specifically asks how the scientific investigation on the potential land use changes were conducted, how reliable the discoveries are, and how they were utilized in multiple steps at different institutions from the proposal evaluations to the approval stages. Our research indicates that scientific findings have rarely been integrated in policy making regarding DPCLS forests in Kepri Province. In addition, the scientific findings are weak; the institution producing them is heavily dominated by government officials and paid consultants/ experts. The scientific body was only established to fulfill the formal processes required by the regulatory frameworks. Proposals and decisions on the changes of DPCLS forests in Kepri Province are more characterized by political considerations. The "scientific findings" of the current land use in Kepri Province is used as a political commodity (or commodities) to support the interests of actors.
\end{abstract}

Keywords: science-policy interface; forest policy; land use change; interest; power; Indonesia

\section{Introduction}

The allocation, use, and management of forests in Indonesia have long been politically contested and are characterized by overlapping and even competing institutions and regulatory frameworks (Brockhaus et al., 2012; Myers et al., 2017). In general, the forest administration has been shaped by dual regimes, that is, forestland and non-forestland (Sahide and Giessen, 2015). The government of Indonesia has gazetted approximately 120 million hectares or approximately two thirds of the country's land as state forest zones that are allocated into three main functions: production, protection, and conservation. Although forests have been gazetted as permanent zones, the legal frameworks allow changes of forest status to respond to the increasing land demands for non-forest uses, such as plantation, agriculture, industrial, and residential sites (Sahide et al., 2018). 
Government Regulation (GR) No. 104/2015 stipulates that any changes in forest zoning, use, and function in Indonesia for economic development purposes must be based on scientific considerations, such as biophysical conditions and carrying capacity, and should be reflected in spatial planning, specifically at the provincial level (Rencana Tata Ruang dan Wilayah Provinsi/ RTRWP). The regulation specifies the important roles of comprehensive evidence-based research by a competent scientific authority to ensure the optimal balance between economic and environmental goals. In practice, land allocation also involves political processes involving various actors and institutions - at local, sub-national, and national levels; interests; and power (Brockhaus et al., 2012; Syahadat and Sabarudi, 2012; Setiawan et al., 2016; Prabowo et al., 2017). This paper assesses the links between both processes, whether research findings are sufficiently used in the political process of land use allocation.

Specifically, the processes related to the changes of Highly Important Forest Zones with Strategic Values (Dampak Penting Cakupan Luas dan bernilai Strategis/DPCLS) are analyzed. DPCLS can be technically classified as vital and high conservation value forests. It is unique as the Forest Law No. 41/1999 stipulates that any changes require approval from the parliament (Dewan Perwakilan Rakyat/ DPR RI) to complement the processes at the Ministry of Environment and Forestry (MoEF). This research uses the case of Riau Islands (Kepulauan Riau/ Kepri) Province, which consists of more than 2,000 islands scattered at the Strait of Malacca among Malay Peninsula, Sumatra, and Borneo (Figure 1). The total area of the province is $251,810.71 \mathrm{~km}^{2}$ with its water territory made up of $95.79 \%$ or $241,215.30 \mathrm{~km}^{2}$. The forest resources extend only $3,880.61 \mathrm{~km}^{2}$ of forestland with an additional mangrove ecosystem of $642.19 \mathrm{~km} 2$. Kepri Province was previously part of Riau (mainland) Province. In contrast to the mainland Riau, which is yet to accept the Consensus-based Forest Land Use Planning (Tata Guna Hutan Kesepakatan/TGHK) of MoEF. Kepri has synchronized the forest maps in its spatial plans.

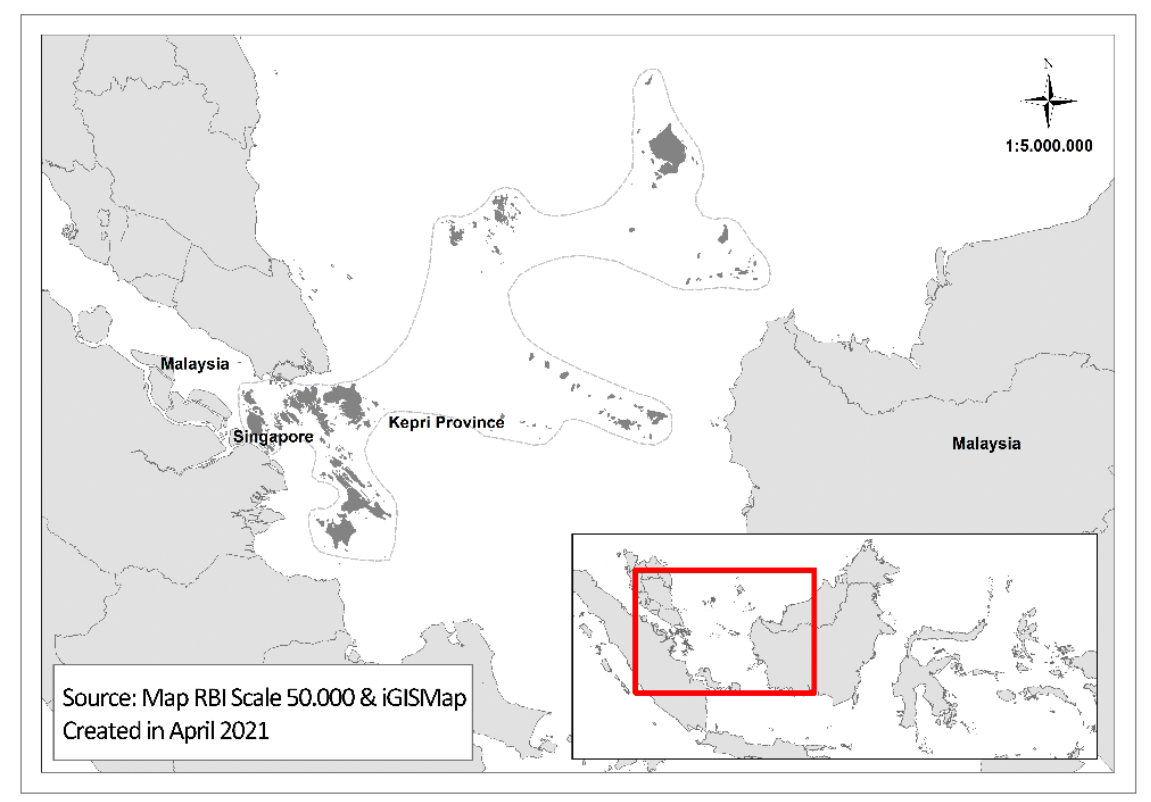

Figure 1. Map of Kepri Province (with own elaboration)

The limited extent of forests in Kepri Province makes some forest resources to be considered vital and important. Over the years, forests have been threatened by conversions for mining activities as the province has a large potential of mineral resources and energy. In addition, the strategic position of the province (e.g., the exclusive free trade zones of Batam, Bintan dan Karimun) potentially encourages further conversions for economic development zones, such as residential areas. Transforming forests into development areas in Kepri Province, as proposed in the revised provincial spatial plans (RTRWP), had been tedious involving relentless conflicts of interests among multiple institutions at different levels. The earliest proposal can be tracked back more than a decade ago, precisely in 2009. It has undergone multiple revisions and is not fully approved due to the perceived unreliability and inaccuracy of so-called scientific foundations. The approval processes 
involve complex and chaotic political conflicts between local and central governments, including the parliament. This paper specifically asks:

- How was the scientific investigation on the potential land use changes conducted?

- How reliable are the discoveries?

- How were they utilized in multiple steps at different institutions from the proposal evaluations to the approval stages?

We observe low confidence in the scientific recommendations for the political decisions on approving DPCLS forests. Scientific findings have rarely been integrated in land use policy making. We further find that proposals and decisions on the changes of DPCLS forests in Kepri Province are characterized by political considerations. Data and information of the scientific findings of current land use in Kepri Province are used as a political commodity to support the interests of actors.

\section{Theoretical considerations}

There is a growing scholarly interest to obtain better understanding on science-policy interaction/ interface in line with the growing promotion of evidence-based policy making. The bottom line of this is that policy makers are encouraged to use scientific information before making political decisions that potentially have considerable impacts and consequences. To assess whether scientific evidence is utilized in land use planning and allocation in Kepri Province, we employ the analytical lens of the RIU model (research, integration, utilization) established by Böcher and Krott (2016). The model initially focuses on the discussion on the transfer of knowledge in the field of forestry and environmental policies. It is also used to explain how research or scientific inquiries affect the politics of policymaking with actors involved rationally in all problem-solving activities.

The RIU model criticizes the classical linear model of knowledge transfer, that is, a linear/technocratic model (Stevanov et al., 2013). In the technocratic model, scientific findings can directly be used as the basis for policymaking deliberations as such findings are often perceived to have a higher value than the political process (Böcher and Krott, 2016). However, Forsyth (2003) argues that science and politics are inseparable and co-produced. In this case, science both influences and is influenced by politics. Policymaking itself is dynamic and involves political processes (Maryudi and Sahide, 2017). Actors may adjust and re-adjust their interests and strategies according to the developing political dynamics (Krott et al., 2014). Thus, a specific process must be used to translate research findings into political decisions. Science is expected to influence a policy, but many cases show that political actors often do not use science or even ignore it instead (Böcher and Krott, 2016). Importantly, data and information are often falsified to the extent that they support actors' interests (Krott, 2005).

In highly contested issues, such as forest land allocation, decisions do not necessarily integrate scientific considerations; they may be based on actors' behaviors and interests. The forest zoning (TGHK) of MoEF is seen as a conceptualization of "political forests" (Peluso and Vandergeest, 2001; 2020). Although TGHK is said to have been based on biophysical considerations, the maps are made on desks and often do not correspond with forested areas (Maryudi, 2015). TGHK is also said to facilitate specific interests for others (Peluso, 1995; Tacconi et al., 2019; Sahide et al., 2018; Fatem et al., 2018). Even the revised (synchronized) TGHK remains problematic to date (Setiawan et al., 2016), suggesting that the conflicting land use in the focal research case is driven by the fundamental problem of science-policy disconnects.

These factors highlight the crucial step of integration to enable the science-policy interface to function. Science integration directs the research on real problems to explain and find solutions. Do et al. (2019) argue that science and political practice work in different realms, and successful knowledge transfer must be based on how to bridge their differences. Specifically, the successful transfer of scientific knowledge must accommodate the practical demands of the political process. Note that meeting political expectations and practical interests does not compromise the quality of science itself (Dharmawan et al., 2017). Integration is thus a bi-directional process between research and political policymaking (Böcher and Krott, 2014). The movement of each activity is adjusted to the specific needs on which the movement is based, depending on the underlying policies or merely practical needs. Integration can be in the form of exchanging information to respond to practical 
needs and gathering evidence (ibid.). In this regard, scientists may need to pursue different integration strategies. Nagasaka et al. (2016) point out scientists can also play as an integrator. The adoption of science in policy making can also be more effective with the support of an individual specialized in both identifying political problems and providing potential solutions (Polsby, 1984). This actor, as Böcher and Krott (2016) stated, can mobilize support from political actors (allies), playing as internal and external supporters for the integration process.

\section{Methods}

This research employed the analytical framework of the RIU model to explain how scientific inquiries meet the politics of policymaking with actors rationally involved in all problem-solving activities (Guston, 2001; Hulme, 2009). As previously mentioned, this study assessed the RIU processes related to the changes of DPCLS forests in Kepri Province. We aimed to describe the underlying factors of the long delay in the approval of DPCLS forest changes; how scientific knowledge, which was expected to be the foundation of the political decisions, was produced; how it was integrated in policymaking; and whether it was utilized. We also emphasized the roles and political positions of related actors.

In addition, we employed established methods commonly used for examining the politics of forest/land use policy and governance (Laraswati et al., 2020). Between August and October 2019, we conducted semi-structured interviews with important actors, including actors involved in integrated research, Kepri provincial government, and political decision makers in the executive (MoEF) and the parliament (DPR RI). The interviews were guided by a list of general stimulating questions around the following themes:

- The manner of balancing development and sustainability goals,

- The meaning of DPCLS to each actor,

- Variables considered significant and critical in making DPCLS approval and decisions,

- Actors' expectations in the changes of the designation and function of DPCLS forests,

- Views on the scientific knowledge of DPCLS.

These topical questions were applied to facilitate ease of communication because of the highly political nature of the research. The aim of the strategy is to encourage interviewees to provide further details in comfortable settings (Maryudi and Fisher, 2020).

In addition, this research utilized several supporting data, such as various regulations regarding the allocation and use of forest data and the specific decrees issued for Kepri Province from repositories (Rahayu et al., 2020). We thus considered the regulatory repositories of MoEF and Ministry of Laws and Human Rights. Our research also benefited from the scientific report produced by the Integrated Research Team (Tim Terpadu/Timdu), including extensive meeting notes and discussion minutes regarding the chronological process at hearings and working meetings at DPR RI between 2012 and 2019.

The observations and reflections of the rich personal experiences of the first, second, and third authors were also used. Between 2014 and 2019 the first author was an expert staff member in the Commission IV of DPR RI in charge of the agriculture, marine, and forestry sectors, all of which dealt with the processes for the allocation of forest land use in Indonesia. The second author was the Director General (DG) of Forestry Planning and Environmental Management (Planologi Kehutanan dan Tata Lingkungan/PKTL) of MoEF between 2015 and 2017. The third author is the DG of PKTL between 2017-2021.

\section{Results}

\subsection{Changes of DPCLS forests-proposals and approval procedures}

Changes of DPCLS forests, regulated by Forest Law No. 41/1999 and its operational regulation (GR No. 104/2015), can be observed through five main stages (Figure 2). Article 30 of GR No. $104 / 2015$ specifically stipulates that the Governor has the authority to propose forest changes, provide recommendations and considerations, conduct technical consultations with the (forestrelated) Minister, and integrate the changes in the provincial spatial plans (RTRWP or revised RTRWP). The Governor's proposal is then put forward to the MoEF as the basis to establish a Timdu 
to conduct a comprehensive scientific study about the forest changes and assessments on their potential adverse impacts. As defined in the regulation, the team is composed of government institutions which "possess scientific competence and authority" and related stakeholders. However, it is usually dominated by the ministry's experts from biophysical, socio-cultural, legal, and institutional aspects. In addition, the team's work is financed by the Provincial Government, and the members are remunerated based on certain standards, covering meetings and data analysis, fieldwork, transportation, and accommodation. Hence, its independence can be in question.

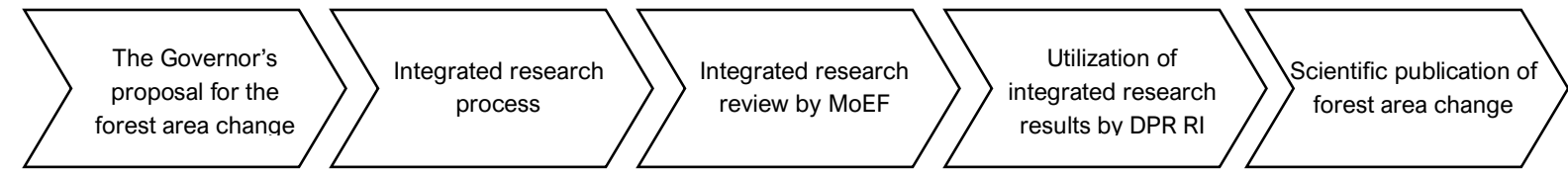

Figure 2. Mechanism for Changing DPCLS Forest Areas

Article 16 of Forestry Minister's Regulation (Permenhut) P.34/2010 states that the ministry's technical team may fully or partially approve/reject Timdu's comprehensive scientific study. The final decision on DPCLS forests is made by DPR RI after the MoEF review. DPR RI may also use Timdu's comprehensive scientific study. Although the same scientific findings are used, the differences between MoEF and DPR may still appear at this stage. Based on the DPR's approval, the Minister of Forestry and Environment must issue a decree on forest change, which the Governor must integrate in the RTRWP. The whole process is to be replicated when the Governor submits a new proposal of changes.

Kepri Province was previously a part of mainland Riau whose spatial plans (RTRWP), as regulated in the Regional Regulation (Perda) No. 10/1994, are yet to match the forest zoning of MoEF. Following the split in 2002, Kepri Province was obliged to create its own spatial plans, but the province only started the formal process in 2009. During the vacant time between 2002 and 2009, several land conversions were gazetted by MoEF, such as converting protection forests into cultivation areas (Bappeda, 2009).

On January 14, 2009, the Governor formally lodged a proposal on the changes of the 594,047 ha of TGHK forest zones; the proposal was intended to be incorporated in the province spatial plan of MoEF (at the time was Ministry of Forestry/MoF) ${ }^{1}$, which responded by establishing a Timdu with Decree No. 676/Menhut-VII/ 2009 dated October 15, 2009. The research team worked for six months to make scientific recommendations as the basis for the Minister to evaluate the province's proposal. In the early months of the following year, the Governor lodged a revised proposal because the initial proposal failed to cover forest changes into non-forest uses (Area Penggunaan Lain/APL); the proposal was also revised to accommodate old villages (Kampung Tua) and communitycultivated lands that have already existed. As the assessment process was dragging on, Timdu's mandate was renewed on September 22, 2010. The following two years saw multiple revisions with new maps as several districts/cities failed to meet the minimum forest coverage of $30 \%$ of the land area. The last revision sent on December 12, 2012, aimed to obtain the signature of all regents/mayors in the province. Overall, Kepri Province has submitted seven proposals for forest changes.

\subsection{Production of scientific basis for forest changes}

The Timdu for land use change in Kepri Province was chaired by an expert from the Indonesian Institute of Sciences and consisted of three experts (academics) from universities, $12 \mathrm{MoEF}$ experts, four inter-ministry experts, three provincial (Kepri) representatives, and a representative from the Indonesian Association of Forest Concession Holders. Looking at the composition, although it is expected to bridge the interests of MoEF and the provincial government, Timdu is more representing the interests of MoEF to keep as much as the forestland and prevent conversion into other uses.

\footnotetext{
1 to avoid confusion, this paper uses MoEF throughout
} 
More importantly, the Timdu is not a scientific/ research team per se, rather a fact-finding team. As stipulated by Law No. 32/2009 on the Protection and Management of the Environment, the team conducted the Strategic Environmental Assessment (Kajian Lingkungan Hidup Strategis/ KLHS) on the potential impacts of the proposed forest changes. Due to the relatively short time frame (six months), the team adopted a quick appraisal/rapid assessment method, comprising an assessment on the potential impacts of a policy/ program and identification of alternative strategies to mitigate the adverse impacts (Sudarwanto, 2010). However, the rapid assessment method heavily relies on the professional judgements of experts using their experience (Kementerian Lingkungan Hidup, 2011). It is often said to only be relevant for less complex problems in contrast to the high potential consequences of forest changes (Widodo et al., 2012). In addition, the rapid approach was considered insufficient to provide a comprehensive analysis on the main issues that are required in KLHS, that is, promoting strategic policy decisions based on sustainability principles, exercising alternative livelihoods, and ensuring democratic (participatory) processes (International Association for Impact Assessment, 2002). As such, the findings and discoveries were not based on careful scientific procedures and steps, and their validity and reliability can thus be questioned.

In October 2012, Timdu submitted its assessment report to MoEF. It found differences between the actual land use and MoEF's TGHK maps produced in 1986 and 1987. For example, many areas were undeclared as forests in the TGHK maps, were forested or at least fell under MoEF's definitions of forests. Therefore, Timdu recommended lands to be transformed into forests. The team also found land uses other than forests in forest zones. Overall, Timdu recommended changes of a total forest land area of 517,166 ha $(23,872$ ha of which are DPCLS forests), instead of 594,047 ha as proposed by the Governor (Kemenhut, 2012).

However, MoEF doubted the sufficiency, validity, and reliability of the data provided by Timdu. Interestingly in this respect is that Timdu is technically an MoEF team member. The recommendations made using a rapid assessment became an area of high concern. MoEF argued that Timdu's report lacked the analysis on environmental carrying capacities (Kemenhut, 2012). MoEF doubted the analysis, which was mostly qualitative, relying on the personal views and experiences of the experts (professional judgments). The ministry's technical team, which reviewed Timdu's recommendations by using its own interpretations of satellite imagery and driven by the political interests of maintaining the forest status, approved the changes of only 6,734 ha DPCLS forests. The ministry's technical team ignored the actual non-forest land uses (e.g., residential, mining fields) within the lands gazetted as forest zones.

\subsection{Political battles using different data}

MoEF forwarded the findings and recommendations of its own technical team to DPR RI on June 27, 2013 for an approval of 6,734 ha DPCLS forests in Kepri Province. On October 1, 2013, DPR $\mathrm{RI}$ invited the then Director General of Forest Planning (now DG PKTL) for an official hearing. The presentations of the MoEF team focused on the materials prepared by its technical team and rarely elaborated Timdu's findings (DPR, 2014a). Some members of DPR RI, as stated in the Minutes of Meetings, felt that they failed to receive adequate explanation from the Ministry regarding the changes of DPCLS forests, including Timdu's findings. Other members argued that DPR RI had been fait accompli by the Ministry and considered the Ministry to only expect the legislative body as a "rubber stamp" (DPR, 2014b).

On the following day, DPR RI held another hearing with the Governor of Kepri. Timdu's findings and recommendations continued to be underused, leading to the hesitation of DPR RI to make decisions. DPR RI decided to conduct field visits from October 17 to 19, 2013 to obtain improved data and information. For the field visits, DPR RI established a working committee (Panitia Kerja/Panja). The Panja found that some areas, which were claimed by MoEF as forests, are used as residential areas, industrial sites, and tourism destinations. DPR RI finally approved the changes of DPCLS forests of only 7,890 ha (DPR, 2014b). This figure is slightly above the number of MoEF but is far below the recommendations of Timdu.

The formal explanation was that DPR RI does not want to be involved in legalizing (illegal) nonforest uses of forestland. However, it failed to explain why DPR RI approved roughly a thousand 
hectares of illegal non-forest used to be formally changed by MoEF. As learned by the first author of this paper (who was part of the visiting team), the approval for a small part of the DPCLS forest change was political. The approved illegal use referred to the business sites owned by those affiliated in the same political party as the Panja chairperson.

Overall, the DPR RI approval was still in MoEF's favor because most parts of the DPCLS forests proposed for changes remained in the status of forestland. It was then used as the basis for the issuance of the Forestry Ministerial Decree No. 463/2013 dated June 27, 2013. The decision was disputed by local government institutions (provincial and district levels, that is, Batam City Chamber of Commerce, Batam Concession Agency, and the Gas Distributor Company/PT PGN) that maintained its initial proposal and filed a lawsuit in the Indonesian Ombudsman against MoEF.

In June of the following year, the Ombudsman mediated a meeting between MoEF's DG of Forest Planning, the Secretary of Provincial Government, the local parliament of Kepri Province, and several other actors in the dispute to find a solution. The Ombudsman eventually ruled through Decree No. 802/ORI-SRT/VIII/2014 that Forestry Ministerial Decree No. 463/2013 was invalid and instead recommended the use of all Timdu's recommendations. Moreover, the Forestry Ministerial Decree No. 463/2013 was said to potentially create business uncertainties regarding the free trade zones of Batam, Bintan, and Karimun. The Ombudsman's ruling was further strengthened by Tanjungpinang State Administrative Court, Medan High State Administrative Court, and the Cassation Decision of the Supreme Court.

In 2015, MoEF issued the Ministerial Decree P.16 as the second amendment of P.34/2010 focusing on how the ministry uses Timdu's recommendations for the approval of forest change proposals. On March 6, 2015, the Minister then requested the approval from the DPR RI of Timdu's initial recommendation of changes of 23,872 ha DPCLS forests in Kepri Province. At this stage, the MoEF proposal already accommodated the interests of Kepri Province. The fact that the numbers of different institutions (MoEF and provincial government) converged did not lead to swift approval. However, new DPR RI (or its members) made political moves to obtain their own benefits from the process. In the following month, the parliament held a consultation on MoEF's new proposal. DG PKTL was also invited for another official hearing. A new working committee (Panja) of DPR RI was established to conduct a field visit to the province in April 2015 for obtaining additional data. In response, on July 6, 2015, the provincial government of Kepri sent new data and information to the Commission IV of DPR RI to support its position. Several field visits, meetings, and consultations were made until 2020, but DPCLS forest changes are yet to be fully approved by DPR RI.

\section{Discussion and Conclusions}

As widely acknowledged, sound and objective scientific evidence can be a key element of good policies/political decisions. Scientists and even politicians themselves often argue that "good science facilitates good policy". Determining how to maximize the use of scientific evidence in policy is thus a key area for further scrutiny and exploration. Political scholars have shown that although comprehensive strategies and evidence-based policy instruments are desired to solve complex forest problems such as land use conflicts, political deliberations often prohibit them (Krott, 2005; Krott and Hasanagas, 2006). This is also reflected in our study, rigor science which can be crucial for decision/ policymaking processes are not always utilized. Even flawed and weak science is more considered (Do et al., 2018). Scientific findings, data, and information are only used to the extent that they support certain interests of the actors involved in the policy processes (Böcher and Krott, 2016).

Land is a finite and precious resource, particularly in regions that are designated for economic development centers or businesses and trade zones, resembling the current condition in Kepri Province. The fierce competitions on land use are hardly surprising; interested actors use all possible resources to ensure that their interests are achieved. Many cases involving land use can be observed in Indonesia (Brockhaus et al., 2012; Setiawan et al., 2016; Fatem et al., 2018); factors that constitute forests, specifically DPCLS forests, are highly politicized in Kepri Province. Our research on the policy processes of DPCLS forest changes of Kepri Province shows a clear science-policy disconnect. We specifically find that Timdu, the scientific body that was formally expected to produce scientific 
recommendations, was only utilized to accomplish, or fulfill the formal processes required by the regulatory frameworks. Looking at its composition, which is dominated by government officials and paid consultants, the team by nature is a non-scientific body, rather than a fact finding/ investigation team. More importantly, the team was unsupported with adequate resources to produce rigorous and sound evidence according to the systematic and standardized procedures and methods. Timdu was seemingly designed to fail in producing good evidence.

We further observe that the limited accurate data and evidence on the constituents of DPCLS and its extent in Kepri Province were designed to allow value-based policymaking processes. Thus, scientific findings were thus largely neglected in policy processes, which were later heavily influenced by the interests of the institutions involved in the approvals of DPCLS forest changes. Do et al. (2019), employing RIU Model in assessing landscape planning in Vietnam, argue that weak integration of scientific evidence in environmental policy is often caused by the weak links between the research bodies to the political process, and the absence of support from powerful actors. We found a similar situation in our case study that Timdu's findings were not even adopted by MoEF (or MoEF), which is technically its superior, because such results failed to fully support the Ministry's interests to maintain the status quo of its "political forests" as laid out in TGHK maps that serve to prevent forest changes as little as possible. Meanwhile, DPR RI (or its members) pursued their own objectives to satisfy the interests of their constituents at the local level.

Overall, we find challenges in the science-policy integration processes for the DPCLS forest changes in Kepri Province. Improving the quality of scientific evidence is important. Data, information, and knowledge are sources of power (Krott et al., 2014). Research is considered the process of producing knowledge by using scientific methods and standards (Stevanov et al., 2013; Heim and Böcher, 2016), which were then regarded as "truth" and useful in making political decisions that can answer practical needs (Jasanoff, 1990). Nonetheless, quality science itself might not be sufficient. Examples are in abundance that quality science is not fully integrated in policymaking processes (for instance see Dharmawan et al., 2017). Our research presents how the transfer of science into policy making is not linear. Integrating scientific findings into policies needs a bi-directional process (Böcher and Krott, 2016), a learning process of understanding the needs, logical thinking, and values of policymakers (Maryudi, 2018). Political actors tend to make compromises with other political actors to determine how far they can take advantage of existing research results. The method and size of the research portion utilized are determined through political lobbying.

Author Contributions: The first author contributed to designing the study, data collection, data analysis and writing. The second and third author contributed to designing the study and supervision. The fourth author contributed to the writing. The fifth author contributed to data analysis. The sixth author contributed to designing the study, data analysis, writing and overall supervision.

Conflicts of Interest: The authors declare no conflict of interest.

Acknowledgements: The research was funded by the Rekognisi Tugas Akhir (RTA) Grant 2021 (No. 3143/UN1.P.III/DIT-LIT/PT/2021) of Universitas Gadjah Mada, Yogyakarta, Indonesia.

\section{References}

Badan Perencanaan Pembangunan Daerah [Bappeda] Provinsi Kepulauan Riau (2009). Paparan Isu Strategis, Permasalahan dan Arah Pembangunan RPJMD 2010-2015.

Böcher, M. (2016). How Does Science-Based Policy Advice Matter in Policy Making? The RIU Model as a Framework for Analyzing and Explaining Processes of Scientific Knowledge Transfer. Forest Policy and Economics, 68, 65-72. https://doi.org/10.1016/j.forpol.2016.04.001

Böcher, M., and Krott, M. (2014). The RIU Model as an Analytical Framework for Scientific Knowledge Transfer: The Case of the "Decision Support System Forest and Climate Change". Biodiversity Conservation, 23, 3641-3656. https://doi.org/10.1007/s10531-014-0820-5

Brockhaus, M., Obidzinski, K., Dermawan, A., Laumonier, Y., and Luttrell, C. (2012). An Overview of Forest and Land Allocation Policies in Indonesia: Is the Current 
Framework Sufficient to Meet the Needs of REDD+? Forest Policy and Economics, 18, 30-37. https://doi.org/10.1016/j.forpol.2011.09.004

Dewan Perwakilan Rakyat/ DPR. (2014a). Kronologis Proses Pembahasan Panja Rencana Tata Ruang Wilayah (RTRW) Provinsi Kepulauan Riau. Materi Presentasi Dirjen Planologi Kementerian Kehutanan.

Dewan Perwakilan Rakyat/ DPR. (2014b). Kronologi Proses Pembahasan Panja Rencana Tata Ruang Wilayah (RTRW) Provinsi Kepulauan Riau. Jakarta

Dharmawan, B., Böcher, M., and Krott, M. (2017). Endangered Mangroves in Segara Anakan, Indonesia: Effective and Failed Problem-Solving Policy Advice. Environmental Management, 60, 409-421. https://doi.org/10.1007/s00267-017-0868-6

Do, T.H., Krott, M., Juerges, N., and Böcher, M. (2018). Red lists in conservation science-policy interfaces: A case study from Vietnam. Biological Conservation, 226, 101-110. https://doi.org/10.1016/j.biocon.2018.07.016

Do, T. H., Juerges, N., Krott, M., \& Böcher, M. (2019). Can landscape planning solve scale mismatches in environmental governance? A case study from Vietnam. Environment and Planning E: Nature and Space, 2(1), 150-177. https://doi.org/10.1177\%2F2514848618822510

Fatem, S. M., Awang, S. A., Pudyatmoko, S., Sahide, M. A. K., Pratama, A. A., and Maryudi, A. (2018). Camouflaging Economic Development Agendas with Forest Conservation Narratives: A Strategy of Lower Governments for Gaining Authority in the Re-centralising Indonesia. Land Use Policy, 78, 699-710. https://doi.org/10.1016/j.landusepol.2018.07.018

Forsyth, T. (2003). Critical political ecology: The politics of environmental science. Routledge, London

Guston, D. H. (2001). Boundary Organizations in Environmental Policy and Science: An Introduction. Science, Technology, \& Human Values, 26(4), 399-408. https://doi.org/10.1177\%2F016224390102600401

Heim, J., and Bocher, M. (2016). CITES and Science: Using the RIU Model to Analyze Institutionalized Scientific Policy Advice in Germany for the Case of Ivory Trade. International Wildlife Law \& Policy, 19(2), 159-175. https://doi.org/10.1080/13880292.2016.1167475

Hulme, M. (2009). Why We Disagree About Climate Change: Understanding Controversy, Inaction, and Opportunity. Cambridge University Press. UK.

International Association for Impact Assessment. (2002). Strategic Environmental Assessment: Performance Criteria. Special Publication Series No. 1, January 2002

Jasanoff, S. (1990). The Fifth Branch: Science Advisers as Policymakers. Cambridge, Mass: Harvard University Press

Kementerian Kehutanan [Kemenhut]. (2012). Laporan Hasil Penelitian Terpadu Perubahan kawasan Hutan dalam Usulan Paduserasi TGHK dengan RTRW Provinsi Kepri.

Krott, M., and Hasanagas, N.D. (2006). Measuring bridges between sectors: Causative evaluation of cross-sectorality. Forest Policy and Economics, 8, 555-563. https://doi.org/10.1016/j.forpol.2005.07.004

Krott, M., Bader, A., Schusser, C., Devkota, R., Maryudi, A., Giessen, L., and Aurenhammer, H. (2014). Actor-centred power: The driving force in decentralised community-based forest governance. Forest Policy and Economics, 49, 34-42. https://doi.org/10.1016/j.forpol.2013.04.012

Krott, M. (2005). Forest Policy Analysis. Netherlands: Springer.

Laraswati, D., Rahayu, S., Pratama, A. A., Soraya, E., Sahide, M. A. K., and Maryudi, A. (2020). Problem-Method Fit in Forest Policy Analysis: Empirical Pre-Orientation for Selecting Tested or Innovative Social-Qualitative Methods. MethodsX, 7, 100794.

https://doi.org/10.1016/j.mex.2020.100794 
Maryudi, A., and Fisher, M. (2020). The Power in the Interview: A Practical Guide for Identifying the Critical Role of Actor Interests in Environment Research. Forest and Society, 4 (1), 142150. http://dx.doi.org/10.24259/fs.v4i1.9132

Maryudi, A., and Sahide, M. A. K. (2017). Research Trend: Power Analyses in Polycentric and Multilevel Forest Governance. Forest Policy and Economics, 81, 65-68. https://doi.org/10.1016/j.forpol.2017.05.003

Myers, R., Intarini, D., Sirait, M. T., and Maryudi, A. (2017). Claiming the Forest: Inclusions and Exclusions Under Indonesia's 'New' Forest Policies on Customary Forests. Land Use Policy, 66, 205-213. https://doi.org/10.1016/j.landusepol.2017.04.039

Nagasaka, K., Böcher, M., and Krott, M. (2016). Are forest researchers only scientists? Case studies on the roles of researchers in Japanese and Swedish forest policy processes. Forest Policy and Economics, 70, 147-154

Polsby, N.W. (1984). Political Innovation in America: The Politics of Policy Initiation. Yale University Press, New Haven.

Prabowo, D., Maryudi, A, Senawi; Imron, M.A. (2017). Conversion of forests into oil palm plantations in West Kalimantan, Indonesia: Insights from actors' power and its dynamics. Forest Policy and Economics, 78, 32-39. https://doi.org/10.1016/j.forpol.2017.01.004

Rahayu, S., Laraswati, D., Pratama, A. A., Permadi, D. B., Sahide, M. A. K., and Maryudi, A. (2019). Research Trend: Hidden Diamonds-The Values and Risks of Online Repository Documents for Forest Policy and Governance Analysis. Forest Policy and Economics, 100, 254-257. https://doi.org/10.1016/j.forpol.2019.01.009

Sahide, M. A. K., and Giessen, L. (2015). The Fragmented Land Use Administration in IndonesiaAnalysing Bureaucratic Responsibilities Influencing Tropical Rainforest Transformation Systems. Land Use Policy, 43, 96-110. https://doi.org/10.1016/j.landusepol.2014.11.005

Sahide, M. A. K., Fisher, M. R., Maryudi, A., Dhiaulhaq, A., Wulandari, C., Kim, Y. S., and Giessen, L. (2018). Deadlock Opportunism in Contesting Conservation Areas in Indonesia. Land Use Policy, 77, 412-442. https://doi.org/10.1016/j.landusepol.2018.05.020

Setiawan, E. N., Maryudi, A., Purwanto, R. H., and Lele, G. (2016). Opposing Interests in the Legalization of Non-Procedural Forest Conversion to Oil Palm in Central Kalimantan, Indonesia. Land Use Policy, 58, 472-481. https://doi.org/10.1016/j.landusepol.2016.08.003

Stevanov, M., Böcher, M., Krott, M., Krajter, S., Vuletic, D., and Orlovic, S. (2013). The Research, Integration and Utilization (RIU) Model as an Analytical Framework for the Professionalization of Departmental Research Organizations: Case Studies of Publicly Funded Forest Research Institutes in Serbia and Croatia. Forest Policy and Economics, 37, 20-28. https://doi.org/10.1016/j.forpol.2013.03.006

Sudarwanto, A.S. (2010). Metode Cepat Pelaksanaan Kajian Lingkungan Hidup Strategis (KLHS) dalam RTRW dan RPJMD Propinsi Kabupaten/ Kota. Jurnal Ekosains, 2(3), 21-27

Syahadat, E., and Subarudi. (2012). Problems on Forest and Land Use System for Revision of Provincial Land Use System. Jurnal Analisis Kebijakan Kehutanan, 9(2)

Tacconi, L., Rodrigues, R.J., and Maryudi, A. (2019). Law enforcement and deforestation: Lessons for Indonesia from Brazil. Forest Policy and Economics, 108, 101943. https://doi.org/10.1016/j.forpol.2019.05.029

Widodo, B., Ribut, L., and Donan, W. (2012). KLHS untuk Pembangunan Daerah Berkelanjutan. Jurnal Sains dan Teknologi Lingkungan, 4(1), 43-54 